\title{
Poduksi Tempe Sebagai Wirausaha Mahasiswa Santri
}

\author{
Aisyah Andayani \& Slamet Hambali \\ Pondok Pesantren Life Skill Daarun Najaah, \\ Universitas Islam Negeri Walisongo Semarang \\ Email : slamethambali1@gmail.com
}

\begin{abstract}
Tempe" is a traditional food in Indonesia that interested almost of all world. Most of vegetarian who using "tempe" as food alternative of meat. Because many devotees of "tempe". "Tempe" is a food that made of soybean seed fermentated by tempe's ragi. Tempe is a source of the best protein also, to result the qualified tempe, need the good tempe also and can process making tempe well and true. Producing tempe is one of for the studnets, or santri of life skill Daarun Najaah to endeavor and exercise autonomous spirit. Remember tempe is a product that interested from a various cityzen. Subservience process are 3 steps : preparation step, implementation step, and evaluation step. Until the student university can market the product tempe to the society, can process product mattered nature of tempebecome, the kind of nutritious food and rightfull with has value of sale, and teach to the society ability of producing tempe.
\end{abstract}

Abstrak: Tempe merupakan makanan tradisional Indonesia yang diminati hampir di seluruh dunia. Banyak kaum vegetarian yang menggunakan tempe sebagai makanan pengganti daging. Tempe adalah makanan yang terbuat dari biji kedelai yang difermentasi menggunakan ragi tempe. Tempe juga merupakan sumber protein yang sangat baik. Untuk menghasilkan tempe yang berkualitas dibutuhkan pula kedelai yang bagus (berkualitas) serta dapat mengelola proses pembuatan dengan baik dan benar. Produksi tempe menjadi salah satu trobosan bagi mahasiswa santri Pondok Pesantren Life Skill Daarun Najaah untuk berwirausaha dan melatih jiwa kemandirian mengingat tempe merupakan produk yang diminati dan digemari dari berbagai lapisan kalangan masyarakat. Proses pengabdian meliputi tiga tahap, yaitu: tahap persiapan, tahap pelaksanaan, dan tahap evaluasi. Dengan adanya tahapan-tahapan tersebut program ini dapat berkelanjutan sehingga mahasiswa santri mampu memasarkan produk tempe kepada masyarakat, mampu mengolah produk berbahan dasar tempe menjadi berbagai makanan bergizi dan halal serta memiliki nilai jual, dan mengajarkan kemampuan produksi tempenya kepada masyarakat.

Kata Kunci: tempe, mahasantri, wirausaha. 


\section{PENDAHULUAN}

Pesantren bisa disebut rumah, baik bagi para perantau yang jauh dari tanah kelahirannya maupun santri yang tanah kelahirannya. Pesantren adalah rumah milik mereka yang sudah bertekad untuk belajar ilmu umum dan ilmu agama. Siapapun dirinya, darimana pun ia, apapun backgroundnya, ketika telah bertekad untuk belajar, mengaji, dan mengabdi pesantrenlah tempatnya. Di tengah kota metropolitan sekalipun pondok pesantren mampu berdiri dengan kokoh dan gagah. Salah satu pondok pesantren yang tumbuh dan berkembang di pinggiran kota yang lambat laun menjadi kota metropolitan adalah Pondok Pesantren Life Skill Daarun Najaah Semarang.

Pondok Pesantren Life Skill Daarun Najaah terletak di Bukit Beringin Lestari Barat Blok C 131 Wonosari, Ngaliyan. Pondok pesantren ini diasuh oleh Dr. KH. Ahmad Izzuddin, M.Ag. dan ibu Nyai Hj. Aisyah Andayani, S.Ag. Pondok pesantren ini merupakan salah satu pondok mahasiswa, kebanyakan santri berasal dari luar Semarang, bahkan banyak pula santri yang berasal dari luar pulau jawa. Seiring berjalannya waktu, untuk mengembangkan kreatifitas dan kemampuan santri, saat ini telah dibentuk beberapa jenis divisi yang dikelola, diantaranya : Divisi Bidang Pemberdayaan Masyarakat, Divisi Kajian Dan Penerbitan, Divisi Pemberdayaan Ekonomi Umat Dan Kewirausahaan, Divisi Pengembangan Bahasa, Divisi Kepemudaan, Olah Raga Seni Dan Budaya, Divisi Penelitian Dan Pelatihan Untuk Umat, Divisi Advokasi Dan Hukum, Divisi Humas Dan Public Relation, Divisi Khusus Pengembangan Kajian Falakiyah Di Antaranya Lembaga Hisab Rukyah “ Al Miiqaat ", Komunitas Falak Santri Indonesia (KFSI), Komunitas Falak Perempuan Indonesia (KFPI), dan Forum Komunikasi Pesantren Falakiyah Indonesia (FKPFI).

Kebutuhan mahasiswa sekaligus santri ini yang menjadikan mereka mencari cara dalam memenuhi kebutuhan mereka. Pada saat ini wirausaha tempe cukup populer dikalangan mahasiswa, mengingat kebanyakan mahasiswa gemar mengkonsumsi tempe goreng untuk menemani makan pagi ataupun makan malam.

Wirausaha pembuatan tempe menjadi salah satu trobosan yang dapat dipilih mahasiswa sekaligus santri. Namun, banyak dari mereka yang tidak mengetahui proses pembuatan tempe yang benar dan sehat. Oleh karena itu pelatihan pembuatan tempe perlu disosialisasikan di Pondok Pesantren Life Skill Daarun Najaah Semarang. Pelatihan pembuatan tempe ini diharapkan mampu melatih jiwa kemandirian dan jiwa kewirausahaan mengingat tempe merupakan produk yang diminati dan digemari dari berbagai lapisan kalangan dan produk 
tempe juga berpotensi di jual di pasaran karena kualitasnya yang baik untuk kesehatan.

Alasan pemilihan santri Pondok Pesantren Life Skill Daarun Najaah sebagai subyek dampingan dalam karya pengabdian ini adalah Banyaknya mahasiswa santri yang memiliki potensi dalam bidang produksi tempe dan pengolahan berbagai macam makanan dengan bahan dasar tempe. Alasan lain berupa realita bahwa di Pondok Pesantren Life Skill Daarun Najaah terdapat santri yang berasal dari berbagai daerah. Melalui kegiatan pelatihan produksi tempe diharapkan selepas pemberdayaan, mahasiswa santri bisa menerapkan di daerahnya masing-masing. Dengan harapan menjadi salah satu penunjang ekonomi kreatif di masyarakat.

\section{POTRET PONDOK PESANTREN LIFE SKILL DAARUN NAJAAH}

Pondok Pesantren Life Skill Daarun Najaah merupakan pesantren yang selalu menanamkan jiwa wirausaha kepada para santri. Hal ini dikarenakan berprinsip bahwa wirausaha merupakan ladang kerja yang dapat memberikan lapangan pekerjaan kepada orang lain sehingga dapat meningkatkan perekonomian masyarakat sesuai dengan harapan bersama. Kedepan, dengan bekal ilmu wirausaha yang di dapatkan di Pesantren, alumni dari Pondok Pesantren Life Skill Daarun Najaah diharapkan mampu menjadi pioneer dalam kehidupan wirausaha di tengah-tangah masyarakat.

Sampai saat ini, wirausaha yang berkembang di Pondok Pesantren Life Skill Daarun Najaah, diantaranya ialah bimbingan belajar, re-packing snack, bakso, jus, penjualan buku-buku islami, kerupuk santri, penjualan pulsa, dan hidroponik serta wirausaha lain yang sedang dirintis, yaitu produksi tempe.

Tempe merupakan makanan khas Indoesia yang digemari oleh masyarakat secara luas. Tempe merupakan salah satu produk hasil olahan berbasis biotekhnologi. Sebagaimana diketahui bahwa tempe merupakan makanan yang memiliki banyak sekali manfaat, seperti kalsium, fosfor, Zat Besi dan Vitamin B1, Selain itu tempe juga mengandung serat pangan yang dapat membantu memenuhi kebutuhan serat harian tubuh. Bahkan tempe sangat baik sebagai sumber protein nabati, dibanding protein hewani seperti daging sapi dan sebagainya, Menurut penelitian, kandungan protein tempe lebih tinggi jika dibandingkan protein dari hewani.

Saat ini, Tempe bahkan telah menjadi pilihan kaum vegetarian di seluruh dunia. Akibatnya saat ini produksi tempe meningkat pesat seiring meningkatnya permintaan dari konsumen. Dengan demikian wirausaha tempe saat ini menjadi pilihan yang cukup menjanjikan dan memiliki prospek yang bagus mengingat 
tempe merupakan bahan makanan yang merakyat dan dapat di olah menjadi berbagai jenis makanan mulai dari makanan yangsederhana hingga makanan berkelas restoran.

Produksi tempe dapat dilakukan dengan mudah, dengan menggunakan kedelai dan ragi sebagai bahan utama. Cara membuatnya juga mudah. Kedelai yang telah dipilih kemudian dicuci bersih, direbus sekitar 60 sampai 90 menit, direndam hingga kulitya mengelupas, dibumbui dengan ragi, lalu dibungkus dengan plastik, daun pisang, atau daun jati. Setelah melalui proses pemeraman selama 36/48 jam tempe dapat di konsumsi.

Produksi tempe bisa dilakukan secara kecil-kecilan di rumah untuk memenuhi kebutuhan sendiri ataupun secara besar-besaran dengan tujuan komersial. Produksi tempe ini sangat cocok di praktikkan di semua daerah. Beberapa kelebihan wirausaha produksi tempe ini antara lain :

1. Ramah lingkungan, karena produksi tempe tidak menggunakan bahan-bahan kimia yang dapat merusak lingkungan.

2. Tidak memerlukan waktu lama dalam proses produksi.

3. Hasil produksi tempe dapat dimanfaatkan sendiri sebagai makanan sehari maupun dipasarkan.

4. Tempe juga dapat dijual dalam bentuk olahan makanan sehari - hari seperti mendoan atau makanan yang tahan lama sepeti keripik tempe.

Kegiatan pemberdayan masyarakat yang diberikan kepada santri Pondok Pesantren Life Skill Daarun Najaah ini bertujuan untuk memberikan pembekalan pada santri sebagai upaya meningkatkan keterampilan santri dalam bidang produksi tempe yang nantinya akan menjadi penunjang ekonomi kreatif di masyarakat. Setelah pelatihan ini diharapkan semua santri Pondok Pesantren Life Skill Daarun Najaah bisa menerapkannya di daerahnya masing-masing. berikut:

Hasil yang diharapkan dari kegiatan pendampingan adalah sebagai

1. Meningkatkan keterampilan mahasiswa santri dalam bidang produksi tempe.

2. Mendapatkan ladang usaha baru dalam menanggulangi pengangguran.

3. Memunculkan kreativitas mahasiswa santri, untuk menunjang ekonomi kreatif di masyarakat.

4. Memberikan keterapilan memasarkan produk kepada masyarakat.

5. Memberikan kemampuan mengolah produk berbahan dasar tempe menjadi berbagai makanan bergizi dan halal serta memiliki nilai jual.

6. Peserta pelatihan dapat mengajarkan kemampuan produksi tempenya 
terhadap masyarakat.

Disamping itu, kegiatan ini juga merupakan manifestasi dari pengembangan kehidupan juga sebagai bentuk ekonomi kreatif masyarakat.

\section{SEKILAS TENTANG TEMPE}

Indonesia adalah negara yang kaya akan banyak keberagaman, baik keberagaman suku, budaya, agama, dan lain-lain. Selain itu Indonesia juga kaya akan berbagai jenis makanan khas di setiap penujuru nusantara. Maka tidak kaget apabila pada waktu itu bangsa-bangsa Barat seperti Portugis, maupun Belanda sangat tertarik kepada Indonesia. Apalagi pada waktu itu Indonesia sangat terkenal dalam menjual berbagai macam rempah-rempah atau bumbu penyedap makanan yang kala itu cukup langka keberadaannya di negara mereka. Hal itu pun semakin diperkuat lagi dengan berkembang dan munculnya olahan-olahan makanan yang secara orijinalitas memang diciptakan asli di Indonesia serta cukup digemari oleh sebagian besar masyarakat, salah satunya yang terkenal adalah tempe (Ido Limando, dkk., t.th).

Tempe merupakan makanan asli khas dari Jawa yang sangat dikenal hampir di seluruh penjuru nusantara. Makanan olahan yang berbahan dasar kedelai tersebut banyak sekali dijual di pasar. Tempe dijadikan sebagai salah satu makanan lauk pokok oleh masyarakat di Indonesia. Tempe atau tempeb sendiri dalam bahasa asing adalah makanan yang dibuat dari fermentasi terhadap biji kedelai atau beberapa bahan lain yang menggunakan beberapa jenis kapang Rhizopus, seperti Rhizopus oligosporus, Rhoryzae, Rh. stolonifer (kapang roti), atau Rh. arrbizus. Sediaan fermentasi ini secara umum dikenal sebagai "ragi tempe". Proses fermentasi pada kapang tempe tersebut membentuk sebuah enzim pencernaan sehingga zat gizi yang terkandung dalam tempe menjadi lebih muda dicerna oleh tubuh dibandingkan yang terdapat dalam kedelai (Rita Ramayulis dan Susianto : 2013, 7).

Berdasarkan sejarahnya, referensi tertua tentang tempe terdapat dalam manuskrip Serat Centini dengan seting Jawa abad ke-2 16 (Serat Centhini sendiri ditulis pada awal abad ke-19) telah ditemukan kata "tempe", misalnya dengan penyebutan nama hidangan jae santen tempe (sejenis masakan tempe dengan santan) dan kadhele tempe srundengan. Makanan tempe bisa dipadukan dengan banyak hal, bisa dimakan dengan nasi, dimakan sebagai lauk di kuah, bisa juga dimakan langsung sebagai camilan sesuai dengan selera setiap orang.

Permasalahan utama di Indonesia tentang tempe adalah seringkali tempe diremehkan sebagai makanan rendahan, serta makanan murah oleh sebagian kalangan di Indonesia. Dengan kata lain banyak orang tahu tentang apa itu 
tempe akan tetapi banyak yang tidak mengetahui sisi positif dan manfaat tempe sebagai makanan asli Indonesia. Padahal tempe adalah makanan yang memiliki banyak khasiat dalam kesehatan karena memiliki kandungan Isoflavon atau merupakan senyawa fitokimia yang ditemukan dalam tumbuhan. Isoflavon sendiri dapat berfungsi untuk menurunkan kolestrol jahat, mengurangi resiko kanker, menurunkan tekanan darah dan lain-lain. Apalagi menurut cerita di perang dunia ke dua, bersumber dari artikel "Warta Biogen Vol. 3, No. 3, Desember 2007”, Tempe adalah makanan yang berhasil menyelamatkan para tawanan-tawanan perang Belanda pada masa pendudukan jepang dari kelaparan. Di mana pada saat itu Roelofsen, salah seorang tawanan berhasil menirukan seorang pribumi dalam membuat tempe dari kedelai. Tempe tersebut memegang peran penting dalam mengurangi laju kematian karena kekurangan protein bagi tawanan pada masa pendudukan Jepang. Seorang tawanan perang lainnya adalah Van Veen juga merasa memiliki hutang budi terhadap tempe karena telah membantu para tawanan perang untuk bertahan hidup (Ido Limando dkk, t.th).

Melihat fakta-fakta menarik tentang tempe tersebut sangat disayangkan apabila ada segilintir orang yang masih merasa bahwa tempe adalah makanan orang miskin dan kampungan bahkan lebih membanggabanggakan makanan dari luar seperti burger, Pizza, dan lain-lain. Tempe adalah makanan yang terkenal dan sangat digemari, khususnya oleh para vegetarian sebagai makanan pengganti daging. Serta pula terdapat cukup banyak bermunculan perusahaanperusahaan tempe di Negara-negara Eropa, Asia Timur bahkan di Amerika sekalipun. Salah satu penyebab hal tersebut disinyalir adalah kurangnya info untuk mempelajari atau belajar lebih jauh tentang tempe itu yang disebabkan oleh minimnya publikasi media terhadap tempe. padahal seperti yang telah diketahui bahwa tempe adalah makanan yang paling terkenal di seluruh penjuru nusantara. Tetapi mengapa pengetahuan masyarakat tentang tempe hanya sebatas pada kulit luarnya saja ? Karena itulah perancangan sebuah buku visual informatif yang menarik, inovatif dan "eye catching" bisa dijadikan sebagai media alternatif serta solusi untuk menanamkan pengetahuan masyarakat yang positif tentang tempe. dan bisa menjadi inspirasi tersendiri bagi masyarakat yang gemar membaca dan mencoba untuk menjalankan usaha tempe (Ido Limando dkk, t.th).

Menurut catatan sejarah yang ada, pada mulanya tempe diproduksi dari kedelai hitam yang berasal dari masyarakat pedesaan tradisional Jawa dan dikembangkan di daerah Mataram, Jawa Tengah dan berkembang sebelum abad ke-16. Selain itu, tempe diperkenalkan oleh orang-orang Tionghoa yang memperoduksi makanan dari kedelai yang difermentasikan dengan 
menggunakan kapang aspergillus. Kemudian, teknik pembuatan tempe menyebar ke seluruh Indonesia (Ido Limando dkk, t.th).

Tempe mulai dikenal oleh masyarakat Eropa melalui orang-orang Belanda. Pada 1895, Prinsen Geerlings, seorang ahli kimia dan mikrobiologi dari Belanda melakukan usaha yang pertama kali untuk mengidentifikasi kapang tempe. Perusahaan-perusahaan tempe yang pertama di Eropa mulai didirikan di Belanda oleh para imigran dari Indonesia. Pada 1946, tempe mulai populer di Eropa (Ido Limando dkk, t.th).

Pada 1984, sudah tercatat sebanyak 18 perusahaan tempe di Eropa, 53 di Amerika, dan delapan di Jepang. Di beberapa negara lain, seperti India, Taiwan, Sri Lanka, Kanada, Australia, Amerika Latin dan Afrika, tempe sudah mulai dikenal di kalangan terbatas. Pada 1940-an, dilakukan usaha untuk memperkenalkan tempe ke Zimbabwe sebagai sumber protein yang murah. Tapi usaha ini tidak berhasil karena masyarakat setempat tidak memiliki pengalaman mengonsumsi makanan hasil fermentasi kapang. Pada masa Perang Dunia II hampir seluruh semenanjung Malaka berada di bawah kendali Jepang (Ido Limando dkk, t.th).

Pada saat tersebut terjadi kekurangan bahan pangan, terutama sumber protein, bagi mereka yang tinggal di penjara. Roelofsen, seorang Belanda yang menjadi tawanan perang di penjara Jepang di Indonesia berhasil meniru orang pribumi membuat tempe dari kedelai. Tempe tersebut memegang peran penting dalam mengurangi laju kematian karena kekurangan protein bagi tawanan pada masa pendudukan Jepang. Seorang tawanan perang lainnya adalah Van Veen yang merasa berhutang terhadap tempe karena teknologi ini telah membantu para tawanan perang untuk bertahan hidup (Ido Limando dkk, t.th).

Indonesia merupakan negara produsen tempe terbesar di dunia dan menjadi pasar kedelai terbesar di Asia. Sebanyak 50\% dari konsumsi kedelai Indonesia dilakukan dalam bentuk tempe, 40\% tahu, dan 10\% dalam bentuk produk lain (seperti tauco, kecap, dan lain-lain). Konsumsi tempe rata-rata per orang per tahun di Indonesia saat ini diduga sekitar 6,45 kg. Pada zaman pendudukan Jepang di Indonesia, para tawanan perang yang diberi makan tempe terhindar dari disentri dan busung lapar. Sejumlah penelitian yang diterbitkan pada tahun 1940-an sampai dengan 1960- an juga menyimpulkan bahwa banyak tahanan Perang Dunia II berhasil selamat karena tempe. Menurut Onghokham, tempe yang kaya protein telah menyelamatkan kesehatan penduduk Indonesia yang padat dan berpenghasilan relatif rendah (Ido Limando dkk, t.th).

Pada akhir 1960-an dan awal 1970-an terjadi sejumlah perubahan dalam pembuatan tempe di Indonesia. Plastik (polietilena) mulai menggantikan daun pisang untuk membungkus tempe, ragi berbasis tepung (diproduksi mulai 1976 oleh Lembaga Ilmu Pengetahuan Indonesia dan banyak digunakan oleh Koperasi Produsen Tempe Tahu Indonesia, KOPTI) mulai menggantikan laru tradisional, dan kedelai impor mulai menggantikan kedelai lokal. Produksi tempe meningkat dan industrinya mulai dimodernisasi pada tahun 1980-an, sebagian 
berkat peran serta Kopti yang berdiri pada 11 Maret 1979 di Jakarta dan pada tahun 1983 telah beranggotakan lebih dari 28.000 produsen tempe dan tahu.

Tempe banyak dikonsumsi di Indonesia, tetapi sekarang telah mendunia. Kaum vegetarian di seluruh dunia banyak yang telah menggunakan tempe sebagai pengganti daging. Akibatnya sekarang tempe diproduksi di banyak tempat di dunia, tidak hanya di Indonesia. Berbagai penelitian di sejumlah negara, seperti Jerman, Jepang, dan Amerika Serikat. Pabrik Tempe pertama di Eropa didirikan di Belanda oleh para pendatang dari Indonesia. Artikel berbahasa Inggris pertama (yang menyebut tentang tempe) muncul pada tahun 1931 dalam buku "Vegetables of the Dutch East Indies ", yang ditulis oleh J.J. Ochse (Ido Limando dkk, t.th).

Artikel yang populer tentang tempe terdiri dari 7 halaman diterbikan di Perancis tahun 1982 dalam Le Compas.Sejarah Tempe di USA Dimana di Amerika Serikat, tempe mulai dikenal baru pada tahun 1946 dengan diterbitkannya "Possible Sources of Proteins for Child Feeding in Underdeveloped Countries", dalam American Journal of Clinical Nutrition. Pada era tahun 60-an ada ketertarikan baru tentang tempe dengan adanya penelitian di Cornell University (New York) dan di USDA Northern Regional Research Center (Illinois). Pada tahun 1961 Mary Otten menjadi yang pertama memproduksi tempe. Jasa terbesar dalam memperkenalkan tempe pada masyarakat Amerika adalah pada The Farm, sebuah komunitas spiritual dan pertanian besar di Summertown, Tennessee. Toko tempe pertama didirikan pada tahun 1975 oleh Mr. Gale Randall di Undadilla, Nebraska. Sebuah artikel yang ditulis oleh R. Rodale dalam "Prevention" tahun 1977 membuat dirinya dan tokonya terkenal secara nasional. Pada era tahun 80 -an pada saat Industri tempe makin meluas, media mulai menunjukan ketertarikan dan muncul berbagai artikel di jurnal-jurnal sains. Selama tahun 1983 sekitar 1 juta tempe diproduksi untuk dipasarkan (Ido Limando dkk, t.th).

\section{KEGIATAN PENGABDIAN WIRAUSAHA TEMPE UNTUK MAHASANTRI}

Kegiatan pengabdian masyarakat di Pondok Pesantren Life Skill Daarun Najaah Semarang didesain dalam bentuk pelatihan pembuatan tempe secara intensif. Pelatihan ini dilaksanakan dengan beberapa tahap. Pertama, tahap persiapan. Pada tahap ini disusun tim pelaksana. Penyusunan tim pelaksana ini sangat penting dilakukan, karena dengan adanya tim pelaksanan ini kegiatan pelatihan pembuatan tempe ini dapat berjalan dengan efektif dan kondusif.

Langkah selanjutnya melakukan Sosialisasi Kepada Santri. Sosialisasi Program Karya Pengabdian Dosen (KPD) kolaboratif Dosen dan Mahasiswa di Pesantren Life Skill Darun Najaah Semarang dilakukan sebelum kegiatan dilaksanakan. Sosialisasi ini dilakukan guna menjaring peserta agar mengikuti 
kegiatan pelatihan pembuatan tempe. Karena kegiatan ini sangat bagus untuk diikuti oleh segenap mahasiswa santri.

Selain itu, sosialisasi ini dilakukan guna menyamakan persepsi mahasiswa santri terkait pentingnya pemanfaatan biji kedelai khususnya untuk pembuatan tempe, karena setelah pelatihan dilaksanakan para santri diharapkan mampu menerapkan dan menyebarluaskan cara pembuatan tempe kepada masyarakat. Dan dari produk tempe tersebut juga dapat dijadikan sebagai wahana wirausaha yang profit, sehingga para mahasiswa santri nantinya tidak akan menjadi pengangguran setelah lulus.

Langkah berikutnya mencari tutor. Setelah mlakukan sosialisasi kepada santri, tim pelaksana pengabdian mencari tutor ahli dalam bidang pembuatan tempe. Sekaligus membahas teknis pelatihan yang efektif dan efisien agar kegiatan pelatihan dapat tepat sasaran. Tutor ahli pembuatan tempe di Pondok Pesantran Life Skill Daarun Najaah Semarang ini berasal dari Rumah Kedelai Grobogan (RKG).

Langkah terakhir dari tahapan ini melakukan koordinasi dengan tim pelaksana. Koordinasi ini bertujuan guna mempersiapkan segala sesuatu yang dibutuhkan untuk pelatihan pembuatan tempe di Pesantren Life Skill Daarun Najaah Semarang. Sehingga kegiatan tersebut nantinya berjalan dengan lancar dan sukses.

Kedua, tahap pelaksanaan. Dalam tahap ini terdapat dua sesi, yang pertama adalah pelatihan pembuatan tempe secara teori yang disampaikan oleh narasumber dari Rumah Kedelai Grobogan (RKG), dan dilanjutkan dengan praktek pembuatan tempe. Langkah pertama, pelatihan efektif teknik proses pembuatan tempe. Kegiatan ini dilaksanakan di Pesantren Life Skill Daarun Najaah yang diikuti 100 mahasiswa santri dari bergabagai daerah yang tersebar di Indonesia. Selain mahasiswa santri, juga dihadiri oleh Pimpinan Pesantren Life Skill Daarun Najaah dan ketua Karya Pengabdian Dosen (KPD) Kolaboratif Dosen dan Mahasiswa yang sekaligus membuka kegiatan ini.

Ketika narasumber dari Rumah Kedelai Grobogan (RKG) menyampaikan materi, para peserta sangat antusias memperhatikan materi yang disampaikan. Karena masih awam bagi para peserta terkait proses pembuatan tempe, tak sedikit peserta yang menanyakan kepada supaya mereka faham apa yang belum mereka ketahui.

Langkah kedua berupa praktek pembuatan tempe. Tempe merupakan produk lokal asli Indonesia yang sangat diminati oleh mayoritas masyarakat. Bahan dasar pembuatan tempe adalai kedelai. Kedelai yang digunakan adalah 
kedelai lokal dari Grobogan karena kedelai lokal ini adalah kedelai non GMO (Genetically Modified Organisms).

GMO (Genetically Modified Organisms) adalah hasil proses laboratorium di mana gen dari satu spesies diekstrak, diartifisial, dan disisipkan ke dalam tanaman atau hewan lain yang tidak saling berhubungan. Gen asing yang disisipkan dapat berasal dari bakteri, virus, serangga, hewan atau bahkan manusia. Tanaman yang sudah jelas transgenik yang ada di Indonesia adalah jagung dan kedelai. Sedangkan tanaman lainnya yang juga termasuk GMO : kentang, tomat, alfalfa, daging, ayam, susu dari hewan yang diberi pakan non organik, dan beras.

Menurut jurnal kesehatan, akibat makanan transgenik ini tidak begitu kelihatan jika dikonsumsi oleh manusia, oleh karena itu ahli biologi menguji cobakan terhadap tikus, dan hasilnya mencengangkan : tikus menjadi mandul, lemah, gerak lakunya lamban, terdapat sel kanker di otak dan saluran cernanya.

Kedelai yang dikonsumsi di Indonesia sebagian besar adalah impor dari AS. Padahal kedelai AS hasil rekayasa genetik (GMO) dari Monsanto. GMO (Genetically Modified Organism) atau makhluk hidup hasil rekayasa genetik sangatlah berbahaya karena dapat menyebabkan penyakit baru. Selain itu rekayasa genetik juga melanggar hukum Sunatullah (hukum dasar penciptaan) karena merusak susunan keseimbangan alam semesta.

Sudah banyak tragedi dalam sejarah manusia yg ditimbulkan oleh GMO, contohnya adalah penyakit kanker, AIDS, dan berbagai virus flu. Saat ini $90 \%$ produk pertanian dan perternakan dunia dikendalikan oleh Monsanto yg merupakan hasil GMO yang berbahaya bagi manusia. Saat ini 90\% produk pertanian dan perternakan dunia dikendalikan oleh Monsanto yg merupakan hasil GMO yang berbahaya bagi manusia. Berikut ini adalah contoh ayam hasil dari rekayasa genetik (GMO) yang juga biasa dikonsumsi penduduk Indonesia (http://marinki.org/2014/02/01/mengenalkan-produk-gmo-dan-efeknegatifnya-terhadap-manusia/).

Dalam praktek pembuatan tempe ini terdapat beberapa proses, sehingga nantinya akan menghasilkan tempe yang higenis. Adapun prosesnya sebagai berikut:

1) Penjemuran. Penjemuran merupakan proses awal pembuatan tempe sebelum produksi. Penjemuran ini berfungsi mengurangi kadar air dari dalam kedelai.;

2) Pengukuran kadar air. Untuk menghasilkan tempe yang berkualitas, ukuran kadar air harus sesuai. Ukuran kadar air dalam kedelai untuk pembuatan tempe yaitu dibawah 14\%, pengukuran ini dilakukan menggunakan alat pengukur. 
3) Sortir, ortir dalam teknik pembuatan tempe bertujuan untuk memisahkan kualitas kedelai yang baik maupun kedelai yang jelek. Kedelai yang berkualitas baik ini yang akan digunakan untuk pembuatan tempe untuk menghasilkan tempe yang berkualitas.

4) Perendaman ke-1. Pada tahap ini, kedelai yang telah disortir kemudian direndam dalam air sekitar 4-5 jam.

5) Perebusan ke-1. Tujuan dari perebusan ke-1 ini adalah melunakkan biji agar biji kedelai dapat menyerap asam pada proses perendaman ke-2 serta mematikan enzim penyebab bau langu. Proses ini membutuhkan waktu 30 menit atau sampai kedelai mendekati setengah matang.

6) Pemisahan Kulit Ari. Proses pemilihan kulit dimulai dengan memisahkan kulit ari kedelai kemudian menghasilkan kedelai tanpa kulit ari.

7) Perendaman ke-2. Perendaman ke-2 ini bertujuan untuk hidrasi bijikedelai dan terjadinya fermentasi agar diperoleh keasaman untuk pertumbuhan fungi. Proses ini membutuhkan waktu 12-18 jam.

8) Perebusan ke-2. Perebusan yang ke-2 ini berfungsi untuk melunakkan biji kedelai dan meminimalkan pertumbuhan bakteri patogen. Pada tahap ini memerlukan waktu sekitar 45 menit sampai 60 menit.

9) Penirisan. Setelah perebusan ke-2, proses selanjutnya yaitu penirisan, penirisan ini memiliki fungsi agar biji kedelai menjadi kering dan dingin. Penirisan memerlukan waktu 15 menit sampai 30 menit.

10) Peragian. Proses peragian dilakukan dengan cara mencapur biji kedelai dan ragi, kemudian aduk hingga merata, adapun takarannya adalah 2-3 g / $15 \mathrm{~kg}$.

11)Pengemasan, Apabila semua tahap-tahap dari penjemuran kedelai sampai peragian maka proses selanjutnya yaitu pengemasan. Kemas kedelai dalam plastik dengan berat 350 gram/bungkus atau kemas menurut kemasan yang diinginkan.

12)Fermentasi. Setelah kedelai telah siap dikemas, proses selanjutnya adalah fermentasi, proses fermentasi dilakukan pada suhu 27 - 30 $\mathrm{C}$ selama 18-36 jam.

13)Tempe jadi. Setelah semua proses sudah terlaksana, maka tempe sudah benar-benar menjadi tempe yang siap didistribusikan atau dimasak berbagai masakan.

Tahapan-tahapan untuk memproduksi tempe sehingga menghasilkan produk tempe yang higienis dan berbeda dengan tempe-tempe yang lain, yaitu:

1) Diproses tanpa bahan pengawet sama sekali, diolah secara higienis dengan mempertahankan nilai gizi dari kedelai itu sendiri. Rasa kedelainya pun lebih 
kuat dan tentu akan menjadikan pengalaman bagi kita setelah memakan tempe dari Pesantren Life Skill Daarun Najaah karena lebih lezat di lidah.

2) Sangat kaya akan protein nabati yang cukup untuk menunjang kebutuhan harian protein kita. Dengan memakan tempe sehat ini, maka kamu mendapatkan kecukupan protein sama hal nya bila mengkonsumsi daging atau ayam.

3) Diolah dari kedelai spesial Non GMO, berbeda dengan tempe yang beredar di pasaran, dimana salah satu yang membedakan adalah dari cara pembuatan sampai dengan status kesehatannya.

4) Proses produksi yang higienis meliputi kebersihan pekerja, peralatan, lingkungan kerja dan kebersihan lingkungan, tapi tidak berhenti disitu saja, karena kami sangat respect dan mempertimbangkan alam, maka bukan hanya higienis tapi juga ramah lingkungan.

5) Mengandung vitamin dan mineral yang dibutuhkan untuk memperkuat tulang dan melancarkan sistem pencernaan. Sangat baik bukan hanya untuk melancarkan pencernaan, namun juga mencegah penyakit kardiovaskuler, karena rendah kalori, rendah kolesterol dan dapat mencegah kanker payudara.

Ketiga, tahap evaluasi dan monitoring. Setelah semua rangkaian tahap dijalani, maka langkah terakhir adalah melakukan evaluasi dan monitoring. Evaluasi ini perlu dilakukan supaya kegiatan ke depannya akan lebih baik. Kegiatan ini juga didesain supaya ke depannya dapat dilaksanakan secara berlanjut dengan dana swadaya masyarakat.

Selain itu, pengawasan atau monitoring pasca kegiatan pelatihan juga penting untuk dilakukan. Pengawasan ini dilakukan dengan sistem koordinasi antara tutor ahli dan pelaksana pengabdian. Pemantauan akan dilakukan selama 1 bulan. Hal-hal yang akan dipantau meliputi kegiatan pembuatan tempe para mahasiswa santri Pondok Pesantren Life Skill Daarun Najaah Semarang, kualitas hasil pembuatan tempe, dan jiwa wirausaha santri dilihat dari pemasaran yang dilakukan setelah produksi.

Dalam pelaksanaan pengabdian masyarakat di Pondok Pesantren Life Skill Daarun Najaah Semarang yang berbentuk pelatihan pembuatan tempe, tim pelaksana sudah bekerja ekstra untuk kesuksesan pengabdian ini. Sebelum pelaksanaan kegiatan dimulai, tim pengabdian jauh-jauh hari sudah mempersiapkan segala sesuatu yang dibutuhkan.

Tim pelaksana kegiatan beberapa kali melakukan koordinasi dengan tutor ahli guna mengemas kegiatan yang menarik dan berbobot. Kegiatan pelatihan pembuatan tempe disambut baik oleh para santri. Hal tersebut terlihat dari 
antusias dan keaktifan para santri untuk mengikuti pelatihan. Dengan adanya pelatihan semacam ini diharapkan para santri untuk bisa mempunyai Skill, sehingga nantinya setelah wisuda tidak menjadi pengamgguran.

\section{ANALISIS PROBLEMATIKA PENGABDIAN}

Meskipun kegiatan pelatihan pembuatan tempe di Pondok Pesantren Life Skill Daarun Najaah Semarang sudah didesain dengan baik dan menarik, namun masih saja terdapat kendala, yaitu:

1. Mahasiswa santri masih belum sadar akan pentingnya kegiatan pelatihan ini, sehingga sebagian dari mereka ada yang menyepelekannya.

2. Kurangnya kreatifitas santri, sehingga kegiatan terkesan kurang meriah.

3. Keterbatasan alat dan bahan, sehingga pembuatan tempe kurang maksimal.

Selain problematika yang telah tercantum di atas, terdapat beberapa problem terkait pembungkus tempe dan air limbah rebusan kedelai. Problem pertama terkait pembungkus tempe. Tempe merupakan bahan makanan yang berasal dari kedelai. Setelah mengalami proses fermentasi, kedelai akan berubah wujud menjadi tempe. Saat difermentasi, biasanya tempe di bungkus dalam suatu wadah agar sempurna proses proses peragiannya. Setelah diberi ragi, tempe akan berubah bentuk seperti bungkusnya.

Beberapa macam pembungkus tempe, seperti pembungkus plastik, daun pisang, dan daun jati. Saat ini dipasaran sering kita temui tempe dengan bungkus plastik, baik yang berbentuk persegi maupun bulat memanjang. Selain itu di daerah semi kota dan desa banyak ditemukan tempe dengan bungkus daun pisang. Bahkan zaman dahulu saat belum umum penggunaan plastik untuk bungkus tempe, orang banyak menggunakan bungkus daun waru. Namun kini bungkus daun waru telah banyak digantikan oleh plastik. Mudahnya memperoleh plastik menjadikan salah satu sebab membanjirnya produk tempe berbungkus plastik. Sementara daun waru sudah sangat sulit mendapatkan, kecuali di pinggir hutan yang makin tergusur oleh pemukiman penduduk. Akan tetapi terdapat problem ketika menggunakan plastic. Plastik akan menimbulkan sampah yang apabila dibakar akan menimbulkan bau yang tidak sedap. Setelah itu akan menimbulkan residu berupa gumpalan plastik yang tidak mudah terurai dalam proses pembusukan.

Selanjutnya pembungkus daun jati. Daun jati juga banyak dipergunakansebagai alat pembungkus atau wadah. Daun jati dimanfaatkan secara tradisional di Jawa sebagai pembungkus, termasuk pembungkus makanan. Aroma daun-daun pembungkus tersebut biasanya terbawa pada makanan yang diwadahi. Akan tetapi daun jati juga memiliki kekurangan jika digunakan untuk 
pembungkus tempe, antara lain yaitu; daunnya kotor dan kasar sehingga terkadang orang yang memakan makanan yang terbungkus dari daun jati terasa gatal.

Adalagi pembungkus daun pisang. Selain daun jati, daun pisang ini juga sering dijumpai untuk pembungkus makanan. Dibanding kekurangannya, daun pisang ini lebih banyak memiliki kelebihan, antara lain, ramah lingkungan, sehat alami, terjaga dari racun kimia berbahaya, lebih nikmat, praktis dan higinis.

Problem berikutnya berupa limbah air rebusan kedelai. Pemanfaatan limbah dari tempe yang sejauh hanya memanfaatkan kulit ari kedelai sebagai makanan ternak. Limbah air dari rebusan kedelai yang tidak diolah secara maksimal akan menghasilkan aroma busuk cukup kuat yang mana itu sangat mengganggu lingkungan. Untuk menanggulangi masalah bau limbah ini, ada solusi mengolah limbah air rebusan kedelai untuk minum ternak, mengentalkan lateks, pupuk tanaman, dan pembuatan biogas (Joko Samudro, 2017). Selain dari ampas kulit ari kedelai yang dapat dimanfaatkan untuk pakan ternak, limbah rebusan kedelai dapat dimanfaatkan sebagai minum ternak. Menurut beberapa hasil penelitian telah diketahui bahwa air rebusan kedelai memiliki kandungan nutrisi yang cukup tinggi dan sangat bagus untuk asupan gizi hewan ternak.

Manfaat selanjutnya untuk mengentalkan lateks. Lateks atau getah karet merupakan hasil dari tumbuhan karet. Lateks ini akan cepat mengental apabila diberi campuran limbah kedelai. Hasilnya juga akan lebih terlihat putih bersih jika dibandingkan dengan campuran-campuran lainnya. Sehingga para petani dapat terbantu dengan adanya limbah air rebusan kedelai ini. Selain itu petani juga akan lebih irit biaya untuk mengentalkan lateks jika dibandingkan harus membeli pupuk atau cuka sebagai campuran lateks. Dalam proses pengentalan lateks ini kita cukup menggunakan limbah murni tanpa ada campuran apapun ke dalamnya. Waktu yang dibutuhkan untuk pengentalan juga relatif lebih cepat jika dibandingkan dengan campuran-campuran lainnya.

Bisa juga untuk pupuk tanaman. Tanaman yang disiram menggunakan limbah ini akan lebih subur dan hijau. Cara penggunaannya adalah siramkan sedikit demi sedikit limbah ke bagian dekat akar tanaman kita. Lakukan seperti biasanya kita menyiram tanaman. Air limbah ini merupakan limbah organik yang mudah terurai dan baik untuk pertanian. Biasanya para petani mencari air untuk mengairi sawahnya dan memanfaatkannya. Selain itu air limbah air rebusan kedelai juga berguna untuk tambahan makanan ikan-ikan peliharaan disawah. Biasanya para petani yang mengelola ikan disawah secara rutin dan terus menerus mengaliri sawahnya untuk makanan ikan dan hasilnya pun ikan cepat besar. 
Kegunaan selanjutnya bisa dipakai untuk pembuatan biogas. Manfaat lain dari limbah air rebusan tempe adalah untuk membuat gas. Meskipun proses pembuatan gas ini relatif lama, namun pembuatan gas ini tetap dilakukan untuk menyalakan kompor mereka. Dengan demikian pencemaran lingkungan akibat limbah kedelai dapat terhindarkan.

Dari beberapa solusi yang ada, Pondok Pesantren Life Skill Daarun Najaah memanfaatkan limbah air rebusan kedelai sebagai minuman untuk hewan ternak sapi yang dimiliki oleh warga sekitar Pesantren. Oleh karena limbah air rebusan kedelai tersebut ditampung di dalam sebuah tempat khusus atau di dalam jerigen penampungan. Kemudian setelah itu akan dikasihkan secara cuma-cuma kepada warga sekitar yang memiliki hewan ternak. Cara penyajiannyapun tanpa harus menggunakan campuran garam. Adapun cara penyajiannya cukup mudah:

a. Tuangkan limbah ke dalam baskom atau ember besar (setengah ember).

b. Campurkan air jernih ke dalam baskom hingga penuh.

c. Jika ada masukkan dedak/katul ke dalam baskom.

d. Aduk hingga rata

e. Kemudian berikan kepada hewan ternak.

\section{KESIMPULAN}

Uraian diatas memberi gambaran upaya membeikan bekal wirausaha kepada santri melalui pembautan tempe. Tempe sebagai produk lokal indonesia dan banyak diminati oleh masyarakat harus dilestarikan dan dikenalkan kepada seluruh khalayak, termasuk santri mahasiswa. Pelaksanaan pembuatan tempe harus ditangani dan dilakukan oleh santri mahasiswa. Dengan demikian santri mahasiswa bisa menyerap dan benar-benar memahami proses pembuatannya dari awal hingga akhir. Satu hal yang luput dari pelatihan pembuatan tempe adalah terkait penanganan limbah yang dihasilkan dari pembuatannya. Bagaimana menangani limbah dari bungkus tempe yang menggunakan pembungkus plastik. Di samping itu juga bagaimana menangani dengan seksama limbah pembuatan tempe yang berupa air sisa pembuatannya. Problem tersebut perlu diperhatikan dan dilakukan secara seksama. Tidak hanya untuk yang sedang mengikuti pelatihan, namun juga kepada pengrajin atau pemroduksi tempe yang tiap harinya menghasilkan air sisa limbah. 


\section{DAFTAR PUSTAKA}

"Daun Pisang, dan Daun Jati," Karya Tulis Ilmiah, Surakarta: Universitas Muhammadiyah Surakarta, 2009.

Azwar, Syaifuddin, Metode Penelitian, Yogyakarta: Pustaka Pelajar, 2004, Cet. Ke 5.

Dkk, Ido Limando, "Perancangan Buku Visual Tentang Tempe Sebagai Salah Satu Makan Masyrakat Indonesia," Penelitian, Surabaya : Universitas Kristen Petra.

Fakultas Syari'ah IAIN Walisongo, Pedoman Penulisan Skripsi,Semarang: Fakultas Syari'ah IAIN Walisongo, 2010.

Hasan, M. Iqbal, Pokok-Pokok Metodologi Penelitian dan Aplikasinya, Bogor : Ghalia Indonesia, 2002.

http:/ / marinki.org/2014/02/01/mengenalkan-produk-gmo-dan-efeknegatifnya-terhadap-manusia/.

Ratna, Nyoman Kutha, Metodologi Penelitian, Yogyakarta : Pustaka Pelajar, 2010.

Arikunto, Suharisimi, Prosedur penelitian Suatu Pendekatan Praktik, Jakarta: PT. Rineka Cipta, 2010.

Susianto, Rita Ramayulis dan, Fakta Ajaib Khasiat Tempe, Jakarta: Penebar Plus, 2013. 